\title{
13
}

\section{Making Transnational Collaboration Work}

\author{
MICHAEL E, GORDON AND LOWELL TURNER
}

The need for transnational collaboration among unions across the world is great and growing in the global economy. Case studies presented in this book demonstrate the active fermentation in cross-border relations and a variety of different approaches, goals, and targets. Yet the barriers to successful collaboration among unions in different countries remain immense: from differences in union structure, ideology, and culture to conflicting interests and differing levels of economic development. What unions have accomplished by operating internationally is important, indeed much more substantial today than ever before. Yet these efforts remain a drop in the bucket compared to the need for coordinated action created by the relentlessly globalizing economy. Unions need closer relations among networks of activists in different countries, between comparable national and local unions, and within multinational corporations. They also need closer relations among key union leaders who, when necessary, can shift resources into transnational cooperation so as to coordinate actions that may lead, ultimately, to cross-border collective bargaining. Finally, unions need a stronger, more coherent and cohesive voice in regulating the global economy, especially in strengthening its much needed "social dimension." Labor's voice should be included among those of decision-makers at the World Trade Organization (WTO), International Monetary Fund, and World Bank, and unions should be guaranteed a role in tripartite trade decisions at the national level.

Taken together, the papers presented in this volume suggest a number of basic principles about the potential success of international cooperation among unions. Defining such principles is a first step toward empirical tests of the efficacy of different collaborative approaches designed to promote the causes of worker and human rights. The experiences examined here suggest the following conclusions for mounting and sustaining successful transnational collaboration. We present them in order of their level of ab- 
straction rather than of their importance: we begin by discussing the necessary atmospheric qualities for successful collaboration and proceed to more specific tactical details.

(1) Resource dependency theory (Pfeffer and Salancik 1978) suggests that, in general, organizations tend to avoid forming controlling relationships that increase their reliance on other entities, even if this means relinquishing only some decision-making autonomy as opposed to more tangible assets. Historically, the threat of loss of autonomy has been one factor cited as a hindrance to greater cooperation among unions (e.g., Ulman 1975). Martin and Ross demonstrate that this concern persists, in their discussion of the obstacles created by national trade unions in Europe to the formation of a transnational industrial relations policy (Chapter 7). Wilson's discussion of the tortuous creation of an international union association and coherent union strategy in the media sector sheds more light on the entropic effects of differing political and professional ideologies (Chapter 8).

Hence the perception of interdependence is an essential precondition for interorganizational cooperation in general and for transnational union collaboration in particular. Such a perception, it seems, must be based upon a commitment to a shared goal the attainment of which is contingent upon the cooperation of individual organizations. In this sense, it appears that international labor associations (e.g., the ITSs and the ICFTU) must attempt to identify superordinate goals that will heighten awareness of trade union interdependence throughout the world. This leads us to our second point.

(2) Despite the advisability of identifying one or more superordinate goals as a means to create labor internationalism, it is clear that traditional ideologies bave not played a substantial role in promoting and maintaining such cooperation. Rather, cooperation has been geared to win very specific, tangible objectives that expand the rights of workers. If anything, the lesson of current international labor activism is that commitment to narrow, traditional ideologies and national interests must be replaced with an expanded open-mindedness to the testing of new tools, including the formation of alliances with groups that have only marginal interests in labor. As unions acquire greater experience from these new structural arrangements, new ideas may emerge that can provide the push of a superordinate goal, including the notion of a "global solidarity movement" (Waterman $1998,349)$ whose strength is derived from allies with strong grassroots interests in ecology, children's and women's issues, and the democratization of global capital.

(3) The collection, analysis, and exchange of information across na- 
tional frontiers are not superficial or secondary activities. Regardless of the nature of workers' objectives (for example, organizing a plant or negotiating a labor contract), and despite the impediments introduced by management, knowledge is a key tool and systematic intelligence is arguably essential for progress. Indeed, Lee (1996) considers the Internet-replete with e-mail, databases, discussion groups, online chat, and electronic publishing - the communication tool that will serve as the foundation for the revival of labor internationalism. This idea is consistent with McLuhan and Powers' (1989) thesis about a "global village" created by electronic media, which decreases the significance of physical presence in people's experience and thereby has the capacity to unify the human race.

Besides reliance on the Internet, information gathering should include existing business and investor databases. These data must be supplemented, however, with sources of information developed and disseminated by workers with first-hand knowledge of management and MNCs, gathered locally and then collated and analyzed at a central clearinghouse. In this vein, Lee (1996) recommends creation of an international online labor press, an online labor archive, and an early-warning network on union rights. Waterman (1998) points out that these proposals, although novel in the realm of organized labor, are consistent with actions already taken by social movernents in other realms, including environmentalism, feminism, and human rights.

(4) Although the world has changed, nothing that we have learned about transnational union collaboration has altered the vital necessity for workers to be willing and able to mobilize and take risks to defend and improve their own working conditions. The severest conflict in unions' international activities still takes place at work sites where workers risk their jobs and well-being in order to establish or maintain collective bargaining rights. Many of the cases in this book discuss local unions and their leaders who endured a great deal of hardship (from strikes to beatings and firings) to persevere in what often turned out to be lengthy struggles. The strength of the "troops on the ground" often determines the willingness of other organizations to support their cause. For example, given its limited resources and the number of requests for assistance it receives, the ICFTU assesses the strength of local support before deciding to support an international campaign (Chapter 5). Although the vigor of local union efforts is an essential ingredient in successful organizing campaigns, Anner (Chapter 12) concludes that it is not sufficient in and of itself to win official union recognition, at least in Central American maquilas. Rather, concerted on-site job actions must be supplemented by effective and imaginative international support that pressures MNCs at their headquarters and in their markets. 
(5) In order to improve the relationship between companies and their employees, union collaboration must first alter existing relationships between employers and various external stakebolder groups. This aspect of transnational collaboration may be understood best in terms of Evan's (1966) concept of the "organization-set," a somewhat stable network of organizations with which a "focal organization" (178) regularly interacts in order to secure inputs or dispose of outputs. In this case the focal organization is the employer. Interactions between the focal organization and each member of its organization-set typically occur for one of the following reasons: exchange (the buying or selling of goods or services); information (the sharing of data of interest to one or both organizations); or normative /the attempted imposition of the values and goals of a member of the organization-set on the focal organization). Transnational union actions invariably are focused on altering these interactions. For example, labor laws define the normative interactions between a government and the corporations operating within its jurisdiction. Transnational union cooperation often entails pressure on governments to strengthen their normative interactions with employers who are ignoring local labor regulations. This scenario was reported by Jessup and Gordon (Chapter 9) and Cohen and Early (Chapter 10) in the Dominican Republic and Mexico, respectively. Transnational pressure also often tries to change the nature of the interactions between a focal organization and its customers. Jessup and Gordon and Anner describe how groups raised the consciousness of customers about the conditions endured by the workers who produced the goods they were about to purchase. At an as yet undefined point, stimulation of the customer's social conscience transforms her/him into a "political consumer-a demanding, ethical, socially-conscious being" (Waterman 1998, 368 ) who is willing to superimpose normative standards on existing economic exchange relationships.

Reporting on a forum on trade policy held at the American Enterprise Institute, Jessup (personal communication, November 24, 1998) noted that "the discussion ... was remarkable for the near unanimous and grudging resignation among free trade policy wonks that labor and environmental issues must now be accommodated on the trade agenda." Adoption of the labor-supported notion of a social clause (Chapter 3) was not favored (suspicion still abounds about protectionist motives of Western unions). However, free traders of the stature of Jagdesh Bhagwati, professor of economics and political science at Columbia University, now recognize that the concerns of advocates for a civil society that places greater emphasis on human and environmental values can no longer be ignored. ${ }^{1}$ It is therefore incumbent upon supporters of free trade to recommend other mechanisms 
to deal with working conditions. At this juncture it is not clear what sort of leverage the new proposals will provide for transnational union collaboration in the future. Nonetheless, these conversations among free traders acknowledge the pervasiveness and significance of customer willingness to impose normative standards on the providers of the goods they buy, and this has obvious implications for international unionism.

(6) Internationalization adds a new level of complexity to labor conflicts, and thus requires a new level of sophistication in union strategy. For example, cross-border campaigns must walk a fine line when pressuring companies to accept unions, so that employers do not simply close the plants. Securing the cooperation of customers, therefore, does not necessarily mean asking them to cancel contracts with the offending employer. Such cancellations can lead and have led to layoffs and even plant closures. Rather, campaigns strive to exert just enough pressure to improve working conditions without crossing a line that leads to major job loss. It is difficult to know the exact location of this line. Bibong Apparel, as we have seen, was pressured from a number of quarters before capitulating and signing a contract (Chapter 9). Disney, on the other hand, bolted from Haiti at the first real signs of organized activity (Chapter 12). Greater experience with cross-border campaigns may enable organizers to forecast employers' re sponses more accurately so that jobs are not lost.

(7) In labor conflicts with an international dimension, often involving anti-labor $\mathrm{MNC}$ activity in a particular country, unions in the nation where the offending multinational is headquartered can play a particularly important role, especially if the firm is significantly unionized at home. Such unions often have leverage with high-level management that can be used to defend worker organizing within overseas subsidiaries operating "unionfree" and determined to stay that way. The IG Metall in Germany is one example of a union that has been able to offer support for foreign unions from its strong position of influence inside German MNCs.

(8) Unions' cross-border campaigns have often been successful when they put a buman face on the conflict. Unions can gain cross-national labor, public, and even shareholder support when they personalize the fight with the anguished expressions of workers who have suffered the loss of their jobs or even physical abuse as a result of their organizing. Other social movements have learned to use this tactic successfully - environmentalists, for example, who involve indigenous groups in public campaigns, from presentations to corporate boards of directors to the building of broad support. ${ }^{2}$ 


\section{Conclusion}

Of the current union strategies for revitalization (including organizing, political action, partnership, mergers, and internal restructuring), international collaboration, although growing, remains the smallest. The current underdeveloped state of transnational cooperation does not make it any less important, however, for the future of modern trade unions-quite the contrary. Government, business, and labor leaders alike appear to be converging on the conclusion that, for better or worse, debates and conflicts on the social dimension of the global economy are growing and will not go away.

The events in Seattle in 1999, and Washington, D.C., in 2000, at meetings of the World Trade Organization (WTO) indicated considerable movement toward increasing normative pressures on employers by linking labor and environmental issues with international trading rights. Dozens of labor, environmental, consumer, human rights, and religious groups demonstrated to open up WTO decision-making, for transparency and to bring in the voice of concerned citizens and interest groups, and to include labor, social, and environmental standards (from collective bargaining rights to protection of rain forests) in global trade agreements. The AFL-CIO played a major role in this broad coalition of protest, contributing to the building of an alternative perspective to footloose globalization, unregulated and massive capital flows (with potentially devastating consequences as evidenced in the Asian economic collapse of 1997-98), and the growing and unchecked economic and political power of MNCs. Although the demonstrations failed to influence the meetings, and although press coverage of the meetings appeared to focus on the militancy of protestors, a few officials, including President Clinton, publicly acknowledged the legitimacy of the demonstrators' claims. These demonstrations are quite possibly a sign of things to come: on the negative side a "mobilization against globalization," on the positive side an opening for activist networking and the spread of international collaboration among unions and others concerned about worker and human rights in the brave new world economy.

Escalating union internationalism is, we believe, essential. If the obstacles are imposing, the possibilities for a prosperous global economy based on strong worker rights, enforceable labor, social, and environmental standards, and diminishing inequality are there to be fought for and claimed. 